\title{
Exploring personality traits and well-being among pre-school and primary school teachers in Croatia
}

\author{
Sanja Tatalović Vorkapicí1.A,C,D,E,F, Irena Peloza $a^{2 \cdot B, E, F}$ \\ 1: Faculty of Teacher Education, University of Rijeka, Croatia \\ 2: Kindergarten "Matulji”, Matulji, Croatia
}

\section{BACKGROUND}

Pre-school and primary school teachers are directly involved in the education of children. In addition to teachers' competences, the quality of their work is significantly influenced by their psychological well-being. It is therefore important to focus on their well-being as well as on personality traits they have. The main objective of this study was to examine the relationship between life satisfaction, happiness, optimism and personality traits of pre-school and primary school teachers in Croatia.

\section{PARTICIPANTS AND PROCEDURE}

The study was conducted on a sample of 103 pre-school teachers and 117 primary school teachers who completed self-evaluated scales on personality traits, life satisfaction, happiness and optimism.

\section{RESULTS}

The results demonstrated high levels of all personality traits in both samples. High levels of life satisfaction were positively associated with happiness and optimism. Personality traits were also positively associated with life satisfaction, happiness and optimism. There were no differences in life satisfaction, happiness, optimism or personality traits between pre-school and primary school teachers, except for openness to experience being higher in pre-school teachers. Emotional stability was a significant predictor of teachers' well-being.

\section{CONCLUSIONS}

The results have significant implications for improvement of teaching practice at primary school and pre-school levels. The findings highlight the importance of teachers' personality traits and their well-being for the quality of their work with children.

\section{KEY WORDS}

well-being; personality traits; pre-school and primary school teachers; Croatia

CORRESPONDING AUthor - Prof. Sanja Tatalović Vorkapić, Faculty of Teacher Education, University of Rijeka, University Avenue 6, 51000 Croatia, e-mail: sanjatv@ufri.hr

AUthors' CONTRIBUtion - A: Study design - B: Data collection - C: Statistical analysis - D: Data interpretation .

E: Manuscript preparation · F: Literature search · G: Funds collection

TO CITE THIS ARTICLE - Tatalović Vorkapić, S., \& Peloza, I. (2017). Exploring the personality traits and well-being among

pre-school and primary school teachers in Croatia. Current Issues in Personality Psychology, 5(1), 21-31.

RECEIVED 03.05.2016 · REVIEWED 17.06.2016 · ACCEPTED 21.01.2017 • PUBLISHED 10.02.2017 


\section{BACKGROUND}

Professional and personal characteristics of pre-school and primary school teachers are expressed in their work with children. When adopting a holistic perspective (e.g., taking into account not only teachers' competences but also teachers' personal characteristics that influence the process of learning and teaching) in the work of pre-school and primary school teachers, it is very important to analyse their personality traits (Tatalović Vorkapić, 2012). This is relevant because teachers' personal properties can determine the course of the learning and teaching process and influence child learning outcomes (Vizek-Vidović, Vlahović-Štetić, Rijavec, \& Miljković, 2014). Empirical findings clearly demonstrated that personality traits have a prominent role within the framework of implicit cognition and implicit pedagogy (Jančec, Tatalović Vorkapić, \& Lepičnik Vodopivec, 2015). This is the process where the individual becomes sensitive to some rules in the environment but with no intention to actually learn. Teachers' implicit pedagogy is significantly related to their teaching competence (Čepić, Tatalović Vorkapić, Lončarić, Anđić, \& Skočić Mihić, 2015). Additionally, teachers' well-being strongly influences group climate in the class (Tatalović Vorkapić \& Jelić Puhalo, 2016), the same as it is greatly influenced by their personality traits (Tatalović Vorkapić \& Lončarić, 2013). Hence, this study examines psychological well-being and personality traits of pre-school and primary teachers. The nature of teacher work requires a great deal of emotional engagement, since the teaching process creates relationships between teachers and children. Therefore, it is important to establish how satisfied teachers are with their life, how happy they are and how these aspects relate to their personality. These issues are particularly relevant for teachers in Croatia, where this study was carried out. For example, job requirements of pre-school and primary school teachers in Croatia are determined by different working methods and evaluation of students' progress. Pre-school teachers work in groups and in pairs, and therefore are mutually responsible for the achievements of their student groups. Thus, all responsibility for the students is on the primary school teacher, who is the only one leading the process of learning and teaching in the class. Due to different determinants of conditions and work methods among the pre-school and primary school teachers (NOK, 2014), we examined the influence of personality traits on teachers' well-being as well as potential differences between pre-school and primary school teachers.

\section{THE RELATIONSHIP BETWEEN PERSONALITY TRAITS AND WELL-BEING AMONG PRE- SCHOOL AND PRIMARY SCHOOL TEACHERS}

In the last few years there has been a significant number of studies on subjective well-being in terms of life satisfaction, happiness and optimism (Rijavec \& Miljković, 2006). These studies have demonstrated that individuals who are satisfied with their lives have more successful marriages, have better social interaction and social relationships, are more immune to stress, and are more efficient in their workplace (Diener \& Biswas-Diener, 2002; Hills \& Argyle, 2001; Lyubomirsky, 2001). Generally, subjective well-being can be best evaluated in conjunction with the individual's personality, which is one of the most reliable predictors of subjective well-being. Individual differences in personality and subjective well-being appear very early in life, are stable and have moderate to strong genetic determination. For example, extraversion and neuroticism correlate most with subjective well-being, whereas extraversion is moderately associated with positive emotions, and neuroticism with negative emotions (Diener \& Lucas, 1999). Personality better explains happiness, life satisfaction and positive emotions than negative emotions, as shown by a meta-analysis of 137 different personality traits (DeNeve \& Copper, 1998). Moreover, all big five dimensions are connected with happiness, but at different levels. Hills and Argyle (2001) determined that extraverted persons and those with minor neuroticism are happier. On one hand, personality dimensions, i.e., conscientiousness, agreeableness and openness to experience, have a relatively low positive correlation with subjective well-being (Diener \& Lucas, 1999). On the other hand, previous Croatian research among pre-school teachers showed significant positive correlations between extraversion, agreeableness, conscientiousness, openness and optimism, hope and life satisfaction, and a negative correlation between neuroticism and mentioned well-being variables (Tatalović Vorkapić \& Jelić Puhalo, 2016). The five-factor model shows that those factors which improve intra-human relationships and successes in goalsetting are important for subjective well-being. Conscientiousness has the strongest connection with life satisfaction, since conscious people set their goals higher and want to achieve more. Positive emotions are evoked by maintaining good relations with people, so they are significantly associated with extraversion and agreeableness. While the emotional component of long-term subjective well-being is more connected with the personality itself, shortterm subjective well-being is more connected with the situational factors than with the personality traits.

Personality traits have a key role in the degree of professional competency, considering the fact that preschool and primary teachers participate in the work of raising and educating children (Tatalović \& Vorkapić, 2012, 2015; Tatalović Vorkapić, Vujičić, \& Čepić, 2014). In teacher samples, personality has been most commonly explored within the Five-Factor personality model. This model indicates that the individual's personality can be explained and understood by five basic personality traits: extraversion, neuroticism, con- 
scientiousness, agreeableness and openness to experience (Goldberg, 1990). So far, high levels of extraversion, conscientiousness, agreeableness and openness to experience, and low levels of neuroticism have been determined among the pre-school and primary school teachers within Croatian studies (Tatalović Vorkapić, 2015). In addition, Tatalović Vorkapić and Lončarić (2013) have found a significant correlation between extraversion, neuroticism, life satisfaction and burnout. Thus, extraversion is positively associated with life satisfaction and negatively with emotional exhaustion. On the other hand, neuroticism has a negative effect on life satisfaction, in a way that increases emotional exhaustion and perception of decreased personal achievement. Openness and conscientiousness through decreasing feelings of diminished personal achievements have direct positive effects on life satisfaction.

In conclusion, teachers play a relevant role in motivating growth and development of the child (Fullan, 2013). They prepare the youngest members of society, in the so-called new pedagogy that is based on the partnership between teachers and children in the process of learning and teaching, which implicitly involves their individual characteristics. Therefore, teachers' well-being and their personality traits are relevant to be explored in the context of this relevant group. In addition, since the relationship of age and work experience with personality and well-being will be explored here, it is important to mention that previous research results showed a negative correlation between teachers' personality traits and well-being with age and work experience (Tatalović Vorkapić, 2012; Tatalović Vorkapić \& Jelić Puhalo, 2016).

\section{RESEARCH AIM AND HYPOTHESES}

The main objective of this study was to examine the relationship between life satisfaction, happiness, optimism and personality traits of pre-school and primary school teachers in Croatia. This is a small country in South-Eastern Europe with a population of about four million people. The important contribution of this research is the fact that there are no similar studies in Croatia or abroad. Also, the novelty and significant implications of this study could contribute to the development of better teaching practice. Therefore we aimed to examine a) levels of life satisfaction, happiness, optimism and personality traits among the pre-school and primary school teachers; b) the relation between personality traits, life satisfaction, happiness, optimism and socio-demographic variables (age and working experience) of pre-school and primary school teachers; c) differences in life satisfaction, happiness, optimism and personality traits between pre-school and primary school teachers; and d) the influence of personality traits on life satisfaction, happiness and optimism among pre-school and primary school teachers.
Considering previous empirical findings, the following hypotheses are postulated: a) high levels of life satisfaction, happiness, optimism, extraversion, conscientiousness, agreeableness, openness to experience and emotional stability among pre-school and primary school teachers; b) significant positive association of life satisfaction, happiness and optimism with personality traits and not with socio-demographic variables; regarding personality traits, a negative correlation with age and working experience is expected due to previous findings (Tatalović Vorkapić \& Jelić Puhalo, 2016); c) no differences between pre-school and primary teachers in their life satisfaction, optimism or personality traits; d) all personality traits will be significant predictors of overall well-being, especially extraversion and emotional stability.

\section{PARTICIPANTS AND PROCEDURE}

This study was conducted on a convenient sample of 220 pre-school teachers (in the range from 24 to 64 years of age, $M=40.04, S D=12.34$ ) and primary school teachers (in the range from 25 to 59 years of age, $M=40.10, S D=9.21$ ). Average working experience of pre-school teachers was $M=18.27, S D=$ 12.28 , in the range from 0 to 43 years of age, and of primary school teachers was $M=17.86, S D=10.62$, in the range from 1 to 36 years of age. Considering the cities, pre-school and primary school teachers are from the city Kastav, Opatija and Rijeka. Twenty-six pre-school teachers work in nursery schools, 61 of them in pre-school groups mixed by age, and thirteen of them in pre-school groups homogeneous by age.

Data were collected in pre-school institutions and elementary schools of the Primorsko-Goranska County as part of a master thesis (Peloza, 2015). The research concerned 9 pre-school institutions and 11 elementary schools in 3 cities previously described. Prior to data collection, a formal invitation for collaboration was sent to all the principals of the pre-school and primary school institutions by the Faculty of Teacher Education. During data collection, the anonymity and confidentiality of participants were guaranteed. All measures have been personally distributed in the preschool and primary school institutions by the first author. Out of 250 distributed surveys, 220 were returned and data collection lasted for two months.

\section{MEASURES}

In this study, four questionnaires were applied to measure personality traits, life satisfaction, happiness and optimism.

The personality traits were measured with the shortened Croatian version of the Ten Item Personality Inventory (TIPI; Gosling, Rentfrow, \& Swann, 
2003; Tatalović Vorkapić, 2016), which consists of 10 items. A sample item is: I see myself as a person who is self-confident and self-disciplined. Subjects self-estimated themselves using a 5-point Likert scale (1 - strongly disagree to 7 - strongly agree). Cronbach's $\alpha$ coefficient of this scale for the pre-school teachers' subsample is $\alpha=.63$, and for the primary school teachers' subsample $\alpha=.72$, which is similar to the validation research (Tatalović Vorkapić, 2016).

Life satisfaction was measured by the Croatian version of the Satisfaction with Life Scale (SWLS; Diener, Emmons, Larsen, \& Griffin, 1985; Diener, Suh, Lucas, \& Smith, 1999; Rijavec, Miljković, \& Brdar, 2008). It consisted of 5 items, such as If I could live my life over, I would change almost nothing. Subjects self-estimated themselves using a 5-point Likert scale (1 - strongly disagree to 5 - strongly agree). Cronbach's $\alpha$ coefficient of this scale for the pre-school teachers' subsample is $\alpha=.87$, and for the primary school teachers' subsample $\alpha=.82$.

Happiness was measured with the Subjective Happiness Scale (SHS; Lyubomirsky \& Lepper, 1999), adapted in Croatia by Rijavec and colleagues (2008). The scale asked participants to globally examine how lucky they are using four items such as In general, I consider myself: from 1 - not a very happy person to 5 - a very happy person. Cronbach's $\alpha$ coefficient of this scale for the pre-school teachers' subsample is $\alpha=.70$, and for the primary school teachers' subsample $\alpha=.58$.

Optimism was measured with the Croatian version of the Revised Life Orientation Test (LOT-R; Rijavec et al., 2008; Scheier, Carver, \& Bridges, 1994). This scale measures optimism with six items such as: I hardly ever expect things to go my way. Subjects self-estimated themselves using a 5-point Likert scale (1 - strongly disagree to 5 - strongly agree). Cronbach's $\alpha$ coefficient of this scale for the pre-school teachers' subsample is $\alpha=.68$, and for the primary school teachers' subsample $\alpha=.69$.

\section{RESULTS AND DISCUSSION}

Analyses were conducted in the following steps. First, we addressed the first research question by using descriptive analysis. Second, correlation analysis was applied, supplemented by the Mann-Whitney test. Finally, hierarchical regression analysis was performed to address the fourth research question.

\section{LIFE SATISFACTION, HAPPINESS, OPTIMISM AND PERSONALITY TRAITS OF PRE-SCHOOL AND PRIMARY SCHOOL TEACHERS}

In relation to the first research question (e.g., the examination of teachers' levels of personality traits and well-being variables), we present basic descriptive analyses in Table 1 . As can be seen, Table 1 shows means and standard deviations for life satisfaction, happiness, optimism and personality traits, separately for pre-school and primary school teachers. Taking into consideration life satisfaction, happiness and optimism, there were high levels with the pre-school and primary teachers in relation to the possible range of results (1-5). In relation to personality traits, we can also see high levels of all personality traits in both samples in consideration of the possible range of results (1-7).

As to personality traits, hope, optimism and life satisfaction among pre-school teachers (Tatalović Vorkapić \& Jelić Puhalo, 2016), the average result on the life satisfaction scale was $M=3.59$. Sabol (2005) has explored personality traits and psychological needs as predictors of life satisfaction and determined an average level of life satisfaction $M=4.48$, but that sample was rather different regarding age and gender. Other authors (Costa \& McCrae, 1985; Eysenck \& Eysenck, 1994) also showed that with age, extraversion decreases, which is directly linked with experiencing positive emotions

Table 1

Sample descriptives

\begin{tabular}{lcccccccccc}
\hline & \multicolumn{4}{c}{ Pre-school teachers } & \multicolumn{5}{c}{ Primary school teachers } \\
\cline { 2 - 11 } & $M$ & $S D$ & Range & Ske & Kur & $M$ & $S D$ & Range & Ske & Kur \\
\hline Life satisfaction & 3.77 & 0.75 & $1-5$ & -0.80 & 0.80 & 3.75 & 0.71 & $1-5$ & -0.31 & -0.94 \\
Happiness & 3.95 & 0.84 & $1-5$ & -1.05 & 1.56 & 3.79 & 0.83 & $1-5$ & -0.89 & 0.76 \\
Optimism & 3.92 & 0.61 & $1-5$ & -0.86 & 2.04 & 3.95 & 0.64 & $1-5$ & -0.70 & 0.68 \\
Extraversion & 4.97 & 1.32 & $1-7$ & -0.15 & -0.53 & 4.84 & 1.29 & $1-7$ & -0.42 & 0.05 \\
Agreeableness & 5.49 & 1.04 & $1-7$ & -0.51 & 0.24 & 5.49 & 1.02 & $1-7$ & -0.35 & -0.84 \\
Conscientiousness & 6.06 & 0.98 & $1-7$ & -1.45 & 1.87 & 5.96 & 1.10 & $1-7$ & -1.09 & 0.10 \\
Emotional stability & 5.45 & 1.23 & $1-7$ & -0.66 & -0.22 & 5.25 & 1.25 & $1-7$ & -0.58 & -0.13 \\
Openness & & & & & & & & & & \\
to experience & 6.02 & 0.99 & $1-7$ & -1.92 & 5.70 & 5.64 & 1.09 & $1-7$ & -0.60 & -0.31 \\
\hline
\end{tabular}

Note. Range - range of results, Ske - skewness, Kur - kurtosis. 
and greater life satisfaction. Similarly, Brkić and Rijavec (2011) examined stress sources, stress coping and life satisfaction of primary teachers, and reported levels of life satisfaction $(M=3.70)$ almost completely coinciding with the result obtained in this research on teachers $(M=3.75)$. Similar are the findings of life satisfaction levels established in other studies, with pre-school teachers (Tatalović Vorkapić \& Lončarić, 2013) as well a general population sample (Lučev \& Tadinac, 2010). Finally, in the research of pre-school teacher's optimism (Tatalović Vorkapić \& Jelić Puhalo, 2016), a higher mean was established than the one obtained in our study $(M=4.51)$. Reasons may be various socio-demographic characteristics of these two samples of pre-school teachers. Regarding personality traits, the findings showed moderate to high levels of all personality traits within the possible range of results. All these findings confirmed prior work on similar samples in Croatia (Tatalović Vorkapić \& Jelić Puhalo, 2016; Tatalović Vorkapić, Čepić, \& Šekulja, 2016).

\section{THE RELATIONSHIP BETWEEN PERSONALITY TRAITS, WELL-BEING VARIABLES, AGE AND WORKING EXPERIENCE}

In relation to research question two (e.g., the relation between personality traits, life satisfaction, hap- piness, optimism and socio-demographic variables (age and working experience) of the pre-school and primary school teachers), Spearman's correlation coefficients were conducted. Table 2 shows correlations and significance levels of life satisfaction, happiness, optimism, extraversion, agreeableness, conscientiousness, emotional stability, openness to experience, age and working experience.

The results from correlation analysis for pre-school teachers are presented above the diagonal, and for primary school teachers under the diagonal. Overall, high levels of life satisfaction for both samples were positively associated with happiness and optimism. All teachers' personality traits were positively associated with life satisfaction, happiness and optimism. However, not all of these relations are significant in both subsamples. The results showed a negative correlation of happiness and optimism with teachers' age and work experience only among primary school teachers. Even though these relations were not significant, it is interesting to observe that extraversion was negatively correlated with age and work experience in the case of primary school teachers, while in the case of pre-school teachers these variables correlated positively. There were no differences in life satisfaction, happiness, optimism and personality traits among pre-school and primary school teachers, except in the case of openness to experience, whose lev-

Table 2

Associations among study variables

\begin{tabular}{|c|c|c|c|c|c|c|c|c|c|c|}
\hline & LS & HAP & OPT & EX & $A G$ & $\mathrm{CO}$ & ES & OPE & Age & TE \\
\hline \multirow{2}{*}{ LS } & \multirow{2}{*}{1} & $.482^{* *}$ & $.460^{* *}$ & -.010 & .132 & $.268^{* *}$ & $.352^{* *}$ & .054 & -.128 & -.058 \\
\hline & & .000 & .000 & .919 & .191 & .007 & .000 & .594 & .302 & .578 \\
\hline \multirow{2}{*}{ HAP } & $.502^{* *}$ & \multirow{2}{*}{1} & $.297^{* *}$ & $.237^{*}$ & .031 & .026 & $.244^{*}$ & .168 & .074 & .107 \\
\hline & .000 & & .004 & .020 & .761 & .802 & .016 & .102 & .556 & .308 \\
\hline \multirow{2}{*}{ OPT } & $.463^{* *}$ & $.362^{* *}$ & \multirow{2}{*}{1} & $.199^{*}$ & .149 & .129 & $.317^{* *}$ & $.407^{* *}$ & .033 & -.079 \\
\hline & .000 & .000 & & .053 & .150 & .212 & .002 & .000 & .793 & .457 \\
\hline \multirow{2}{*}{ EX } & .178 & $.233^{*}$ & $.256^{* *}$ & \multirow{2}{*}{1} & -.099 & .010 & .102 & $.367^{* *}$ & .092 & .062 \\
\hline & .064 & .014 & .007 & & .332 & .922 & .311 & .000 & .464 & .556 \\
\hline \multirow{2}{*}{$A G$} & $.246^{* *}$ & $.227^{*}$ & $.313^{* *}$ & .109 & \multirow[b]{2}{*}{1} & $.262^{* *}$ & $.441^{* *}$ & $.361^{* *}$ & $-.277^{*}$ & $-.223^{*}$ \\
\hline & .010 & .016 & .001 & .263 & & .009 & .000 & .000 & .024 & .032 \\
\hline \multirow{2}{*}{$\mathrm{CO}$} & $.288^{* *}$ & $.219^{*}$ & $.392^{* *}$ & .064 & $.493^{* *}$ & \multirow[b]{2}{*}{1} & $.328^{* *}$ & .149 & .131 & .019 \\
\hline & .002 & .019 & .000 & .503 & .000 & & .001 & .140 & .293 & .857 \\
\hline \multirow{2}{*}{ ES } & $.283^{* *}$ & $.338^{* *}$ & $.537^{* *}$ & $.323^{* *}$ & $.457^{* *}$ & $.387^{* *}$ & \multirow{2}{*}{1} & $.325^{* *}$ & .053 & -.079 \\
\hline & .002 & .000 & .000 & .001 & .000 & .000 & & .001 & .671 & .450 \\
\hline \multirow{2}{*}{ OPE } & $.269^{* *}$ & $.189^{*}$ & $.366^{* *}$ & $.412^{* *}$ & $.332^{* *}$ & $.378^{* *}$ & $.391^{* *}$ & \multirow{2}{*}{1} & .008 & -.083 \\
\hline & .004 & .042 & .000 & .000 & .000 & .000 & .000 & & .952 & .428 \\
\hline \multirow{2}{*}{ Age } & -.123 & -.191 & $-.303^{* *}$ & -.115 & $-.261^{*}$ & -.203 & $-.296^{* *}$ & -.168 & \multirow[b]{2}{*}{1} & $.924^{* *}$ \\
\hline & .282 & .094 & .008 & .325 & .023 & .074 & .009 & .139 & & .000 \\
\hline \multirow{2}{*}{ TE } & -.089 & $-.218^{*}$ & $-.231^{*}$ & -.009 & $-.239^{* *}$ & $-.237^{* *}$ & $-.303^{* *}$ & $-.226^{*}$ & $.955^{* *}$ & \multirow{2}{*}{1} \\
\hline & .357 & .023 & .017 & .930 & .014 & .014 & .001 & .018 & .000 & \\
\hline
\end{tabular}

Note. ${ }^{*} p<.05 ;{ }^{* *} p<.01$. LS - Life satisfaction, HAP - Happiness, OPT - Optimism, EX - Extraversion, AG - Agreeableness, CO - Conscientiousness, ES - Emotional stability, OPE - Openness to experience, TE - Teaching experience. 
el is increased in pre-school teachers. Regarding the connection between life satisfaction and optimism, it has been established that life satisfaction positively and significantly correlated with happiness and optimism within both subsamples. These results were expected and indicated that pre-school and primary school teachers who are highly optimistic are also happier and more satisfied with life. These findings have confirmed results from previous studies (Brkljačić \& Kaliterna Lipovčan, 2010; Družić, Popović, \& Haneš, 2012; Jovanović, 2010).

The pre-school and primary school teachers who are devoted to their work set goals that are achievable and could be fulfilled by various strategies and methods. Considering the fact that the educational process is unstable and full of unexpected new situations, it is important that these educational workers retain high optimism. The present research has confirmed this and agrees with the results of previous studies. Within the group of pre-school teachers, life satisfaction positively correlates with personality traits of conscientiousness and emotional stability. Similar to this finding is the one established in the research of Tatalović Vorkapić and Jelić Puhalo (2016) where a positive correlation was found between life satisfaction and all five personality traits. In addition, it is interesting that in the subsample of primary school teachers, a positive correlation between life satisfaction and personality traits was noted for all personality traits except for extraversion. This result was expected if we compare it with the results of previous research (Hayes \& Joseph, 2002; Hrebičkova, Blatny, \& Jelinek, 2010). The significant positive correlation between openness to experience and life satisfaction only in the subsample of primary school teachers is interesting, and it should be thoroughly explored in future studies with a bigger sample and a more reliable personality measure.

In contrast to life satisfaction, which does not correlate significantly with extraversion, a significant positive correlation between happiness and extraversion could be observed in both subsamples. Happiness correlated positively with all other personality traits in the group of primary school teachers, and negatively with working experience. As to the group of pre-school teachers, happiness correlated positively with emotional stability. In a research study by Lučev and Tadinac (2010) about the relationship between personality traits and life satisfaction, it was established that all personality traits positively correlated with life satisfaction, except neuroticism. Furthermore, Joshanloo and Afshari (2011), exploring personality traits and self-evaluations as predictors of the students' life satisfaction, obtained results which demonstrated significant correlations between all the personality traits and life satisfaction. As with life satisfaction and happiness, optimism correlated positively with emotional stability and openness to experience among pre-school teachers. In the group of primary school teachers, our results have shown that optimism significantly correlates with all personality traits. It is interesting that only in the case of primary school teachers did optimism correlate negatively with age. Previous studies (Penezić, 1996, 1999; Lance, Mallard, \& Michalos, 1995) have shown that age and life satisfaction were not significantly related. The same was confirmed by the research of Raboteg-Šarić, Merkaš, and Majić (2011) in which the adolescents' hope and optimism in relation to their parents' educational style were examined. Considering the intercorrelation between personality traits, the findings from this study have confirmed prior results (Tatalović Vorkapić, 2012).

Furthermore, we found that working experience correlated negatively with agreeableness in the group of pre-school teachers and with the agreeableness, conscientiousness, emotional stability and openness to experience in the group of primary school teachers. It is interesting that in other studies, working experience and age (Tatalović Vorkapić \& Gović, 2016; Tatalović Vorkapić \& Jelić Puhalo, 2016) correlated negatively with extraversion, which was not the case in the present study. Also, age correlated negatively with agreeableness in both groups. It is interesting that in both groups age was not significantly connected with extraversion and emotional stability, as also shown in the previous studies (Tatalović Vorkapić, 2012). Regarding the group of primary school teachers, age correlated negatively with conscientiousness, emotional stability and optimism. These different correlation paths could be explained by various working conditions of pre-school and primary school teachers. The main implication of these findings could be associated with creating specific life-long learning programs or programs for professional development that would enable educators to retain optimal levels of their personality traits and optimism at work.

\section{DIFFERENCE ANALYSIS OF PERSONALITY \\ TRAITS AND WELL-BEING AMONG PRESCHOOL AND PRIMARY SCHOOL TEACHERS}

In relation to the third research question (e.g., differences in well-being and personality traits between pre-school and primary school teachers), Table 3 presents the results of the Mann-Whitney test. There were no significant differences in life satisfaction, happiness and optimism between pre-school and primary school teachers. Considering the similarity between the professions of pre-school and primary school teachers and their work conditions, these results are expected. In the research conducted by Lučić (2007), pre-school and primary school teachers shared an equal opinion of their professions. This perception 
Table 3

Group comparisons

\begin{tabular}{|c|c|c|c|c|}
\hline & & $M$ & $S D$ & $M-W$ test $(p)$ \\
\hline \multirow{2}{*}{ Life satisfaction } & Pre-school teachers & 3.77 & 0.75 & \multirow{2}{*}{.652} \\
\hline & Primary school teachers & 3.75 & 0.71 & \\
\hline \multirow{2}{*}{ Happiness } & Pre-school teachers & 3.95 & 0.84 & \multirow{2}{*}{.108} \\
\hline & Primary school teachers & 3.79 & 0.83 & \\
\hline \multirow{2}{*}{ Optimism } & Pre-school teachers & 3.92 & 0.61 & \multirow{2}{*}{.748} \\
\hline & Primary school teachers & 3.95 & 0.64 & \\
\hline \multirow{2}{*}{ Extraversion } & Pre-school teachers & 4.97 & 1.32 & \multirow{2}{*}{.594} \\
\hline & Primary school teachers & 4.84 & 1.29 & \\
\hline \multirow{2}{*}{ Agreeableness } & Pre-school teachers & 5.49 & 1.04 & \multirow{2}{*}{.986} \\
\hline & Primary school teachers & 5.49 & 1.02 & \\
\hline \multirow{2}{*}{ Conscientiousness } & Pre-school teachers & 6.06 & 0.98 & \multirow{2}{*}{.886} \\
\hline & Primary school teachers & 5.96 & 1.10 & \\
\hline \multirow{2}{*}{ Emotional stability } & Pre-school teachers & 5.45 & 1.23 & \multirow{2}{*}{.212} \\
\hline & Primary school teachers & 5.25 & 1.25 & \\
\hline \multirow{2}{*}{$\begin{array}{l}\text { Openness } \\
\text { to experience }\end{array}$} & Pre-school teachers & 6.02 & 0.99 & \multirow{2}{*}{.008} \\
\hline & Primary school teachers & 5.64 & 1.09 & \\
\hline
\end{tabular}

of their profession can partially serve as an explanation for similar findings on the examined well-being variables. Agreeableness was established as one of the most significant personality traits, and academic self-image in prediction of the variance of examined motivation aspects for the career choice of a teacher. Therefore, personality traits have a strong role when choosing an appropriate profession, besides life satisfaction as a consequence of a proper choice. These findings have been confirmed by the study of Tatalović Vorkapić et al. (2016) with a student sample. Although this particular research was performed on students, it can be compared with the present study, because the participants were students whose future professions are pre-school and primary school teachers. Therefore, in the analysis of testing differences between pre-school and primary school teachers in their personality traits, only one significant difference was established in the trait openness to experience (see Table 3), where the pre-school teachers showed significantly higher results. A possible explanation for this result lies in the different study programs and work method in the pre-school institutions and primary schools. An early and preschool curriculum is structured to enhance and motivate pre-school teachers' openness to new experiences, flexibility, creativity and innovativeness - all personality properties that are not supported within the primary school curriculum and primary school system in Croatia.

\section{TEACHERS' PERSONALITY TRAITS AS POSSIBLE PREDICTORS OF LIFE SATISFACTION, HAPPINESS AND OPTIMISM}

Finally, we aimed at exploring predictors of life satisfaction, happiness and optimism among pre-school and primary school teachers by means of $3 \times 2$ hierarchical regression analyses. The results for primary school teachers are presented in Table 4 . As it can be seen, emotional stability is the only significant predictor of two well-being variables: life satisfaction and optimism. These results are expected due to correlation coefficients previously calculated. The more primary school teachers are emotionally stable, the more they are optimistic and satisfied with life. Emotional stability explains $18 \%$ of total life satisfaction variance and even more, i.e., $46 \%$ of total variance of optimism. Therefore, it could be concluded that this personality trait is very important within the personality profile of primary school teachers and has predictive power regarding the teachers' optimism. Further analyses in the second step showed that happiness explains $31 \%$ of life satisfaction variance, and vice versa, life satisfaction explains $19 \%$ of happiness variance. Age and working experience demonstrated no significant predictive power regarding well-being variables. The results from the hierarchical regression analyses for pre-school teachers can be seen in Table 5 . 
Table 4

Testing predictors in primary school teachers' sample

\begin{tabular}{|c|c|c|c|c|c|c|c|c|c|}
\hline \multirow{2}{*}{$\begin{array}{l}\text { Primary school teachers } \\
\text { Predictors }\end{array}$} & \multicolumn{3}{|c|}{ Life satisfaction } & \multicolumn{3}{|c|}{ Happiness } & \multicolumn{3}{|c|}{ Optimism } \\
\hline & $B$ & $S E B$ & $\beta$ & $B$ & $S E B$ & $\beta$ & $B$ & $S E B$ & $\beta$ \\
\hline & $2.89^{* *}$ & 0.72 & & $2.64^{* *}$ & 0.88 & & $1.68^{* *}$ & 0.49 & \\
\hline Extraversion & 0.07 & 0.08 & .12 & 0.05 & 0.10 & .08 & 0.02 & 0.05 & .04 \\
\hline Agreeableness & -0.21 & 0.12 & -.27 & -0.09 & 0.14 & -.10 & -0.01 & 0.08 & -.02 \\
\hline Conscientiousness & 0.05 & 0.11 & .06 & 0.24 & 0.13 & .29 & 0.06 & 0.07 & .10 \\
\hline Emotional stability & $0.16^{*}$ & 0.08 & .30 & 0.06 & 0.10 & .11 & $0.23^{* *}$ & 0.05 & .52 \\
\hline Openness to experience & 0.11 & 0.10 & .15 & -0.06 & 0.12 & -.07 & 0.12 & 0.07 & .20 \\
\hline Life satisfaction & & & & $0.39^{*}$ & 0.16 & .34 & 0.17 & 0.09 & .21 \\
\hline Happiness & $0.25^{*}$ & 0.10 & .29 & & & & 0.02 & 0.08 & .02 \\
\hline Optimism & 0.35 & 0.18 & .29 & 0.05 & 0.24 & .04 & & & \\
\hline Age & -0.02 & 0.03 & -.27 & 0.04 & 0.04 & .37 & -0.01 & 0.02 & -.18 \\
\hline Teaching experience & 0.03 & 0.03 & .36 & -0.03 & 0.04 & -.29 & -0.00 & 0.02 & -.02 \\
\hline \multicolumn{10}{|l|}{ Model } \\
\hline 1 & \multicolumn{3}{|c|}{$\begin{array}{c}R=.43^{*} \quad R^{2}= \\
F_{(5,58)}=2.58^{*}\end{array}$} & \multicolumn{3}{|c|}{$\begin{array}{c}R=.30 \quad R^{2}=. \\
F_{(5,58)}=1.13\end{array}$} & \multicolumn{3}{|c|}{$F_{(5,58)}=10.02^{* *}$} \\
\hline 2 & \multicolumn{3}{|c|}{$\begin{array}{c}R=.56^{* *} \quad R^{2}=.31 \\
F_{(2,56)}=5.42^{* *}\end{array}$} & \multicolumn{3}{|c|}{$F_{(2,56)}=3.42^{*}$} & \multicolumn{3}{|c|}{$F_{(2,56)}=2.19$} \\
\hline 3 & \multicolumn{3}{|c|}{$\begin{array}{c}R=.57 \quad R^{2}=.3 \\
F_{(2,54)}=0.59\end{array}$} & \multicolumn{3}{|c|}{$F_{(2,54)}=0.52$} & \multicolumn{3}{|c|}{$F_{(2,54)}=1.86$} \\
\hline
\end{tabular}

Note. ${ }^{*} p<.05 ;{ }^{* *} p<.01$.

Considering personality traits as well-being predictors, it was found that emotional stability was a significant predictor only for optimism. However, more significant predictive power in explaining optimism among pre-school teachers is observed for openness to experience. Both of them explain $43 \%$ of optimism variance. Furthermore, as expected, personality traits were not significant predictors for life satisfaction, contrary to extraversion for happiness. Regarding the interrelationship between well-being variables, life satisfaction was a significant predictor for both happiness and optimism, and vice versa, happiness and optimism are significant predictors for life satisfaction of pre-school teachers. Brkljačić and Kaliterna Lipovčan (2010) have determined that satisfaction with individual aspects of life defined $52 \%$ of happiness variances. As in the sample of primary school teachers, age and teaching experience showed no significant predictive power for well-being among pre-school teachers.

\section{CONCLUSIONS}

The goal of this study was to examine the relationship between life satisfaction, happiness, optimism and personality traits of pre-school teachers and primary school teachers in Croatia. High levels of life satisfaction, happiness and optimism were established in both teachers' samples. Similarly, high levels of all personality traits were determined with regards to extraversion, agreeableness, conscientiousness, emotional stability and openness to experience for both groups. These results were expected considering previous studies. One significant difference within the personality traits was for the trait openness to experience, which was significantly higher among pre-school teachers than for primary school teachers. High levels of life satisfaction among pre-school and primary school teachers are positively associated with their happiness and optimism. All personality traits were positively connected with life satisfaction, happiness and optimism, except in the case of the pre-school teachers, where extraversion correlated negatively with life satisfaction. Overall, personality traits showed a higher and stronger correlation with well-being variables among primary school teachers than among pre-school teachers. These two subsamples showed different correlation paths between personality traits and socio-demographic variables, i.e., age and work experience. Finally, emotional stability was found to be the most significant and consistent predictor of well-being. The main contribution of this 
Table 5

Testing predictors in pre-school teachers' sample

\begin{tabular}{|c|c|c|c|c|c|c|c|c|c|}
\hline \multirow{2}{*}{$\begin{array}{l}\text { Pre-school teachers } \\
\text { Predictors }\end{array}$} & \multicolumn{3}{|c|}{ Life satisfaction } & \multicolumn{3}{|c|}{ Happiness } & \multicolumn{3}{|c|}{ Optimism } \\
\hline & $B$ & $S E B$ & $\beta$ & $B$ & $S E B$ & $\beta$ & $B$ & $S E B$ & $\beta$ \\
\hline & 1.26 & 0.88 & & $3.08^{* *}$ & 1.20 & & $1.20^{*}$ & 0.61 & \\
\hline Extraversion & -0.03 & 0.08 & -.05 & $0.23^{*}$ & 0.12 & .31 & -0.01 & 0.06 & -.03 \\
\hline Agreeableness & 0.03 & 0.12 & .05 & -0.11 & 0.16 & -.12 & -0.04 & 0.08 & -.06 \\
\hline Conscientiousness & 0.16 & 0.11 & .21 & 0.00 & 0.15 & .00 & 0.06 & 0.08 & .09 \\
\hline Emotional stability & 0.14 & 0.09 & .24 & 0.10 & 0.13 & .13 & $0.17^{*}$ & 0.07 & .33 \\
\hline Openness to experience & 0.11 & 0.12 & .15 & -0.06 & 0.17 & -.06 & $0.29^{* *}$ & 0.08 & .47 \\
\hline Life satisfaction & & & & $0.45^{*}$ & 0.20 & .34 & $0.23^{*}$ & 0.10 & .27 \\
\hline Happiness & $0.22^{*}$ & 0.10 & .28 & & & & 0.01 & 0.08 & .01 \\
\hline Optimism & $0.42^{*}$ & 0.19 & .35 & 0.02 & 0.29 & .01 & & & \\
\hline Age & -0.02 & 0.02 & -.26 & 0.02 & 0.02 & .30 & 0.00 & 0.01 & .08 \\
\hline Teaching experience & 0.01 & 0.01 & .09 & -0.02 & 0.02 & -.19 & 0.00 & 0.01 & .01 \\
\hline \multicolumn{10}{|l|}{ Model } \\
\hline 1 & \multicolumn{3}{|c|}{$\begin{array}{c}R=.43 \quad R^{2}= \\
F_{(5,48)}=2.14\end{array}$} & \multicolumn{3}{|c|}{$\begin{array}{cl}R=.33 & R^{2}=.11 \\
F_{(5,48)}= & 1.19\end{array}$} & \multicolumn{3}{|c|}{$=7.18^{* *}$} \\
\hline 2 & \multicolumn{3}{|c|}{$\begin{array}{c}R=.58^{* *} \quad R^{2}=.3 \\
F_{(2,46)}=5.56^{* *}\end{array}$} & \multicolumn{3}{|c|}{$\begin{array}{c}R=.46 \quad R^{2}= \\
F_{(2,46)}=2.82\end{array}$} & \multicolumn{3}{|c|}{$=2.81$} \\
\hline 3 & \multicolumn{3}{|c|}{$F_{(2,54)}=1.06$} & $\begin{aligned} R= & .48 \\
& F_{(2,}\end{aligned}$ & $F_{(2,54)}=0.67$ & & \multicolumn{2}{|c|}{$F_{(2,54)}=0.29$} & \\
\hline
\end{tabular}

Note. ${ }^{*} p<.05 ;{ }^{* *} p<.01$.

research is in the fact that similar work is lacking in Croatia, which is relevant since personality traits and teachers' well-being strongly influence class climate and educational outcomes in kindergarten and primary school. Therefore, it is important to investigate the field of various psychological characteristics of educators in Croatia, and worldwide. However, the sample was not representative, since it included preschool and primary school teachers just from one Croatian county. In future research, a much bigger sample should be used. Furthermore, the TIPI (Ten Item Personality Inventory) showed relatively low levels of reliability, which suggests the need for caution in the use of personality measures in future.

Despite these limitations, we can conclude that preschool and primary teachers are of crucial importance for the quality of early education and this study has shown the importance and need for further research in the area of their personality and well-being. Analysing these teachers' personal characteristics, a significant improvement could be assured within their educational work. Their professional development can be successfully developed through various formal and informal training that could directly influence the quality of their work with pre-school and schoolaged children (NOK, 2014). More satisfied, optimis- tic and happy pre-school and primary school teachers with enhanced extraversion, emotional stability, openness to new experiences, conscientiousness and agreeableness are able to create a better and higher quality learning environment for children than those with a lower level of well-being and lower levels of mentioned personality traits. Therefore, self-work within study programs and professional development for both pre-school and primary school teachers are greatly needed, based on these research findings.

\section{RefERENCES}

Brkić, I., \& Rijavec, M. (2011). Izvori stresa, suočavanje sa stresom i životno zadovoljstvo učitelja razredne i predmetne nastave [Sources of stress, ways of facing stress and life satisfaction of primary school teachers]. Napredak, 152, 211-225.

Brkljačić, T., \& Kaliterna Lipovčan, L. (2010). Zadovoljstvo životom i osjećaj sreće kod studenata [Life satisfaction and feeling of happiness among students]. Suvremena Psihologija, 13, 189-201.

Costa, P. T. Jr., \& McCrae, R. R. (1985). The NEO Personality Inventory. Odessa, FL: Psychological Assessment Resources. 
Čepić, R., Tatalović Vorkapić, S., Lončarić, D., Anđić, S., \& Skočić Mihić, S. (2015). Considering transversal competences, personality and reputation in the context of the teachers' professional development. International Education Studies, 8, 8-20.

DeNeve, K. M., \& Cooper H. (1998). The happy personality: A meta-analysis of 137 personality traits and subjective well-being. Psychological Bulletin, 124, 197-229.

Diener, E., \& Biswas-Diener, R. (2002). Will money increase subjective well-being? A literature review and guide to needed research. Social Indicators Research, 57, 119-169.

Diener, E., Emmons, R. A., Larsen, R. J., \& Griffin, S. (1985). The satisfaction with life scale. Journal of Personality Assessment, 49, 71-75.

Diener, E., \& Lucas, R. E. (1999). Personality and subjective well-being. In D. Kahneman, E. Diener, \& N. Schwarz (eds.), Well-being: The foundations of hedonic psychology (pp. 213-229). New York: Russell Sage Foundation.

Diener, E., Suh, E. M., Lucas, R. E., \& Smith, H. E. (1999). Subjective well-being: Three decades of progress. Psychological Bulletin, 125, 276-302.

Družić, T., Popović, D., \& Haneš, O. (2012). Povezanost optimizma sa zadovoljstvom kvalitete života pacijenata sa hroničnom boli [The relationship between optimism and life quality satisfaction among patients with chronic pain]. In S. Jandrić (ed.), $A b$ stract Book of the Fourth International Congress of Physiatrists in Bosnia and Herzegovina (pp. 81-82).

Eysenck, H. J., \& Eysenck, S. B. G. (1994). Priručnik za Eysenckove skale ličnosti: EPS-odrasli [A manual for Eysenck's personality scales: EPS-adults]. Jastrebarsko: Naklada Slap.

Fullan, M. (2013). The New Pedagogy: Students and Teachers as Learning Partners. Learning Landscapes, 6, 23-29.

Goldberg, L. R. (1990). An alternative "description of personality": The big-five factor structure. Journal of Personality and Social Psychology, 59, 1216-1229.

Gosling, S. D., Rentfrow, P. J., \& Swann Jr., W. B. (2003). A very brief measure of the Big-Five personality domains. Journal of Research in Personality, 37, 504-528.

Hayes, N., \& Joseph, S. (2002). Big 5 correlate of three measures of subjective well-being. Personality and Individual Differences, 34, 723-727.

Hills, P., \& Argyle, M. (2001). Happiness, introversion-extraversion and happy introverts. Personality \& Individual Differences, 30, 595-608.

Hrebičkova, M., Blatny, M., \& Jelinek, M. (2010). Osobnost jako prediktor osobni pohody $\mathrm{v}$ dospelosti [Personality as a Predictor of Subjective Well-Being in Adulthood]. Ceskoslovenska Psychologie, 54, $32-42$.

Jančec, L., Tatalović Vorkapić, S., \& Lepičnik Vodopivec, J. (2015). Hidden curriculum determinants in (pre)school institutions: Implicit cognition in action. In Z. Jin (ed.), Exploring implicit cognition: learning, memory, and social-cognitive processes (pp. 216-242). Zhengzhou Normal University, China \& University of California, Davis, USA, IGI-Global, USA.

Joshanloo, M., \& Afshari, S. (2011). Big five personality traits and self-esteem as predictors of life satisfaction in Iranian Muslim university students. Journal of Happiness Studies, 12, 105-113.

Jovanović, V. (2010). Validacija kratke skale subjektivnog blagostanja [Validity of the short subjective well-being scale]. Primenjena Psihologija, 2, 175-190.

Lance, C. E., Mallard, A. G., \& Michalos, A. C. (1995). Tests of the causal directions of global: Life facet satisfaction relationships. Social Indicators $R^{-}$ search, 34, 69-92.

Lučev, I., \& Tadinac, M. (2010). Provjera dvaju modela subjektivne dobrobiti te povezanosti zadovoljstva životom, demografskih varijabli i osobina ličnosti [Examination of the Two Models of Subjective Well-Being and Correlations between Satisfaction with Life, Demographic Variables and Personality Traits]. Migracijske i Etničke Teme, 26, 263-296.

Lučić, K. (2007). Odgojiteljska profesija u suvremenoj odgojno - obrazovnoj ustanovi [Educator profession in a contemporary educational institution]. Odgojne Znanosti, 9, 151-165.

Lyubomirsky, S. (2001). Why are some people happier than others? The role of cognitive and motivational processes in well-being. American Psychologist, 56, 239-249.

Lyubomirsky, S., \& Lepper, H. S. (1999). A measure of subjective happiness: Preliminary reliability and construct validation. Social Indicators Research, 46, 137-155.

NOK, Nacionalni kurikulum za rani i predškolski odgoj i obrazovanje (2014). Zagreb: Republika Hrvatska, Ministarstvo znanosti, obrazovanja i sporta [The National Framework Curriculum of the Pre-school Education. Zagreb: Ministry of Science, Education \& Sport: Republic of Croatia]. Retrieved from http://www.azoo.hr/images/strucni2015/NacionaIni-kurikulum-za-rani-i-predskolski-odgoj-i-obrazovanje.pdf

Peloza, I. (2015). Zadovoljstvo životom, optimizam, sreća $i$ osobine ličnosti odgajatelja $i$ učitelja: Ima li razlike? [Life satisfaction, optimism, happiness and personality traits among pre-school and primary school teachers: Are there any differences? Unpublished master thesis]. Faculty of Teacher Education, University of Rijeka, Croatia.

Penezić, Z. (1996). Zadovoljstvo životom: Provjera konstrukta [Life satisfaction: Construct testing. Graduate thesis]. Zadar: Filozofski fakultet.

Penezić, Z. (1999). Zadovoljstvo životom: Relacije sa životnom dobi i nekim osobnim značajkama [Life 
satisfaction: Relations with age and some other personal features. Master thesis]. Filozofski fakultet u Zagrebu, University of Rijeka, Croatia.

Raboteg-Šarić, Z., Merkaš, M., \& Majić, M. (2011). Nada i optimizam adolescenata u odnosu na roditeljski odgojni stil [Adolescents' hope and optimism in relation to parental child-rearing styles]. Napredak, 152, 373-388.

Rijavec, M., \& Miljković, D. (2006). Tko su dobri ljudi? Psihologija pozitivne osobe [Who are the good people? The psychology of positive persons]. Zagreb: IEP.

Rijavec, M., Miljković, D., \& Brdar, I. (2008). Pozitivna psihologija [Positive psychology]. Zagreb: IEP.

Sabol, J. (2005). Osobine ličnosti i osnovne psihološke potrebe kao prediktori zadovoljstva životom [Personality traits and basic psychological needs as predictors of life satisfaction. Graduate thesis]. Department of Psychology, Faculty of Humanities and Social Sciences, University of Zagreb, Croatia.

Scheier, M. F., Carver, C. S., \& Bridges, M. W. (1994). Distinguishing optimism from neuroticism (and trait-anxiety, self-mastery and self-esteem): a reevaluation of the Life Orientation Test. Journal of Personality and Social Psychology, 67, 1063-1078.

Slunjski, E. (2003). Devet lica jednog odgajatelja [Nine faces of pre-school teacher]. Zagreb: Mali profesor.

Tatalović Vorkapić, S. (2012). The significance of preschool teacher's personality in early childhood education: Analysis of Eysenck's and Big Five dimensions of personality. International Journal of Psychology and Behavioral Sciences, 2, 28-37.

Tatalović Vorkapić, S. (2015). How much personality is important in educational context? In: M. Orel (ed.), International Conference EDUvision 2015: "Modern Approaches to Teaching Coming Generation” (pp. 75-83). EDUvision, Stanislav Jurjevčič, Ljubljana, Slovenija. Retrieved from http://eduvision.si/Content/Docs/Zbornik\%20prispevkov\%20 EDUvision\%202015.pdf

Tatalović Vorkapić, S. (2016). Ten Item Personality Inventory: A validation study on a Croatian adult sample. In Z. Bekirogullari, M. Y. Minas, \& R. X. Thambusamy (eds.), The European Proceedings of Social \& Behavioural Sciences (pp. 192-202). The $4^{\text {th }}$ icCSBs Abstract Book: The Annual International Conference on Cognitive-social, and Behavioural Sciences, Cyprus, 07-10. May, Future Academy.

Tatalović Vorkapić, S., Čepić, R., \& Šekulja, I. (2016). Are there any differences in personality traits and life satisfaction between future pre-school and primary school teachers? Journal of Research in Childhood Education, 30, 361-373.

Tatalović Vorkapić, S., \& Gović, A. (in press). The relationship between flow and personality traits among preschool teachers. Metodički obzori.
Tatalović Vorkapić, S., \& Jelić Puhalo, J. (2016). Povezanost osobina ličnosti, nade, optimizma i zadovoljstva životom odgojitelja predškolske djece [The connection of personality traits of pre-school teachers with their hopes, optimism and life satisfaction]. Napredak, 157, 205-220.

Tatalović Vorkapić, S., \& Lončarić, D. (2013). Posreduje li profesionalno sagorijevanje učinke osobina ličnosti na zadovoljstvo životom odgojitelja predškolske djece? [Does professional burnout mediate the effects of personality traits on life satisfaction among preschool teachers?]. Psychological Topics, 22, 431-445.

Tatalović Vorkapić, S., \& Puljić, I. (2013). Importance of students' personality traits for their future work with preschool children. Metodički Obzori, 8, 34-46.

Tatalović Vorkapić, S., Vujičić, L., \& Čepić, R. (2014). Pre-school teacher identity. In P. Breen (ed.), Cases on Teacher Identity, Diversity, and Cognition in Higher Education (pp. 22-60). A volume in the Advances in Higher Education and professional Development (AHEPD). Book Series, IGI Global. doi: 10.4018/978-1-4666-5990-2

Vizek-Vidović, V., Vlahović-Štetić, V., Rijavec, M., \& Miljković, D. (2014). Psihologija obrazovanja [Educational psychology]. Zagreb: IEP-Vern. 